\title{
Evaluation of anti-tumorigenic activity of BP3B against colon cancer with patient- derived tumor xenograft model
}

\author{
Hye-Youn Kim', Jinhee Kim², Huyen Trang Ha Thi', Ok-Sun Bang ${ }^{2}$, Won-Suk Lee ${ }^{3}$ and Suntaek Hong ${ }^{1 *}$
}

\begin{abstract}
Background: KIOM-CRC\#BP3B (BP3B) is a novel herbal prescription that is composed of three plant extracts. Our preliminary study identified that BP3B exhibited potent anti-proliferative activity against various types of cancer cell lines in vitro. Because the in vivo anti-tumor effect of BP3B is not evaluated before clinical trial, we want to test it using patient's samples.

Methods: To confirm the in vivo anti-cancer effect of BP3B, we used genetically characterized patient-derived colon tumor xenograft (PDTX) mouse model. Anti-cancer activity was evaluated with apoptosis, proliferation, angiogenesis and histological analysis.

Results: Oral administration of BP3B significantly inhibited the tumor growth in two PDTX models. Furthermore, TUNEL assay showed that BP3B induced apoptosis of tumor tissues, which was associated with degradation of PARP and Caspase 8 and activation of Caspase 3. We also observed that BP3B inhibited cancer cell proliferation by down-regulation of Cyclin D1 and induction of p27 proteins. Inhibition of angiogenesis in BP3B-treated group was observed with immunofluorescence staining using CD31 and Tie-2 antibodies.
\end{abstract}

Conclusion: These findings indicated that BP3B has a strong growth-inhibitory activity against colon cancer in in vivo model and will be a good therapeutic candidate for treatment of refractory colon cancer.

Keywords: BP3B, Colon cancer, Patient-derived tumor xenograft, Medicinal plant

\section{Background}

Colorectal cancer is a serious health problem that has progressively increased to be one of the most common cancers worldwide [1]. Combined therapeutic approaches, such as surgery, chemotherapy and radiation were applied to patients with colorectal cancer. Enormous progress has been made during last decade using fluorouracil (FU) to treat colorectal cancer, with a doubling in dose intensity or tumor response through combined treatment with leucovorin (LV) or bevacizumab or through continuous intravenous administration of FU instead of a bolus injection [2]. In recent years, the chemotherapeutic agents (irinotecan (CPT-11) and oxaliplatin) have resulted in significant progress in the treatment of advanced colorectal cancer.

\footnotetext{
* Correspondence: sthong@gachon.ac.kr

'Department of Biochemistry, Lee Gil Ya Cancer and Diabetes Institute, Gachon University, 155 Gaetbel-ro Yeonsu-gu, Incheon 21999, Republic of Korea Full list of author information is available at the end of the article
}

Initial treatment with irinotecan infused FU/LV, commonly known as IFL, resulted in significant increases in response rate, time to disease progression and median overall survival $[3,4]$. However, retrospective analyses suggested that the administration of IFL might be limited to patients with a performance status of 0 [5]. When oxaliplatin infused LVFU-2 regimen was compared with a treatment of oxaliplatin plus LVFU-2, known as FOLFOX4, the latter treatment significantly increased the response rate and the time to progression to 9.0 months. The increase in median survival from 14.7 to 16.2 months did not reach statistical significance [6]. Unfortunately, the metastasis and recurrence of colorectal cancer after curative surgery or resistance to chemotherapy eventually lead to a half of colon cancer patients still die [7].

Since cancer is a very complex disease with multiple known and unknown regulatory mechanisms, treating of cancer based on single target mechanism could be less 
effective than using multi-target strategy $[8,9]$. Combination chemotherapies, commonly known as cocktail therapies, targeting diverse abnormalities of cancer, have shown better treatment outcome from various clinical studies $[10,11]$. In terms of this fact, natural herbal medicines traditionally used for various disease management, could be valuable sources in developing anti-cancer drugs due to their multi-target/multi-component nature. Herbal prescription may amplify the therapeutic efficacies of each herbal component, exhibiting maximum outcome with less side effects [12]. The traditional usage of these medicinal plants has been successfully performed for preventing asthma, reducing edema, relieving fever, cough, hemorrhages, diarrhea and protecting liver [12].

For research of tumor biology or evaluation of anticancer drugs, in vivo xenograft models have been performed extensively [13, 14]. However, most of these in vivo models are based on a limited number of cancer cells previously isolated from tumors and selected prior to implantation in animals. Unfortunately, these in vivo models were difficult to reproduce the tumor microenvironment and cancer cell adaptation to the innate immune system, both of which are essential to architecture of the primary tumors, proliferation and metastasis [15]. In contrast, patient-derived tumor xenograft (PDTX) model obtained by engraftment of patient biopsies transplanted directly into non-obese diabetic/severe combined immunodeficiency (NOD/SCID) mice, subcutaneously, seems to be able to reduce the biologic differences between the primary patient tumor and the in vivo model [16]. In recent years, PDTX models that have been characterized for predicting drug response in various cancer types [17] and used in numerous preclinical studies [18].

The present study aimed to evaluate the anti-cancer effect of KIOM-CRC\#BP3B (BP3B), which is novel herbal prescription of ethanol extract of three medicinal plants on colon cancer using PDTX model. The components of BP3B are Descurainia sophia seed, Peucedanum radix (Peucedanum praeruptorum Dunn.) and Alnus japonica branch. Several reports including our previous study identified that the seeds of D. sophia contained several cytotoxic and anti-inflammatory substances to induce the death of various cancer cell lines in vitro [19-21]. We also showed that pyranocoumarins from $P$. praeruptorum possessed considerably significant multidrug-resistant reversal activity in multidrug resistant MES-SA/Dx5 cancer cells [22]. A. japonica as well contained anti-proliferative and pro-apoptotic compounds that kill some cancer cells such as human leukemia and prostate cancer [23, 24]. Although these three plant materials possessed potential anti-cancer activities, it is very important to measure the anti-cancer activity of herbal mixtures in a reliable in vivo model system. To confirm the anti-tumorigenic activity of $\mathrm{BP} 3 \mathrm{~B}$ against colon cancer, we investigated the changes of histopathological characteristics, proliferation, angiogenesis and apoptotic cell death in colon tumor tissues.

\section{Methods \\ Reagents}

Antibodies against Pecam-1 (M-20:sc-1506),PARP (H250:sc-7150) and Tie-2 (H-176:sc-9026) were purchased from Santa Cruz Biotechnology (Santa Cruz, CA). Antibodies against p27 ${ }^{\mathrm{kip} 1}$ (\#3688) and Cleaved-Caspase-3 (\#9661) were obtained from Cell Signaling (Beverly, MA). Anti-Ki67 antibody was purchased from Vector laboratories (Burlingame, CA). Anti- $\beta$-actin (A5441) was purchased from Sigma-Aldrich (St. Louis, MO). The 4'6-Diamino-2phenylindole dihydrochloride was purchased from Thermo Fisher (Waltham, MA).

\section{Preparation of KIOM-CRC\#BP3B}

The dried seeds of Descurainia sophia, roots of Peucedanum praeruptorum Dunn. and branches of Alnus japonica were purchased from Kwangmyungdang Medicinal Herbs Co. (Ulsan, Republic of Korea). The identities of each herb material were formally confirmed by Dr. Go Ya Choi, KHerb Research Center, Korea Institute of Oriental Medicine. All voucher specimens have been deposited at KMConvergence Research Division, Korea Institute of Oriental Medicine. A whole extract of each herb was separately prepared. In brief, dried plant materials were finely pulverized and immersed in $70 \%(\mathrm{v} / \mathrm{v})$ ethanol $(100 \mathrm{~g} / \mathrm{L})$. Then, the solvent extraction was performed by maceration at room temperature ( $48 \mathrm{~h}$, three times). The extract solutions were filtered through a Whatman filter paper No. 2 (Whatman International, Maidstonem, UK), concentrated using a EYELA rotary evaporation system (Tokyo Rikakikai, Tokyo, Japan) and dried a WiseVen vacuum oven (WOW-70, Daihan Scientific, Seoul, Republic of Korea) to produce a $70 \%$ ethanol extract. The dried powder of extract was homogenized and then stored in the dark at $4{ }^{\circ} \mathrm{C}$ until use. KIOMCRC\#BP3B was prepared by mixing the three herbal extracts at an equal ratio, 1:1:1 (w/w/w). KIOM-CRC\#BP3B was dissolved in $0.5 \%$ Na-carboxymethyl cellulose (Na-CMC) solution right before being used in animal experiments.

\section{Generation of colon PDTX model and in vivo drug efficacy test}

The 6-8 week old male $n u / n u$ mice (Orient Bio, Seongnam, Korea) were used for in vivo studies and all experiments using immunodeficient mice were carried out in accordance with the guidelines approved by Institutional Animal Care and Use Committees of Gachon University. Fresh surgical tumor tissues $\left(\mathrm{F}_{0}\right)$ were collected immediately after surgery from Gil hospital (Incheon, Korea) and cut into 1 $\sim 2 \mathrm{~mm}^{3}$-sized pieces in antibiotics-containing RPMI medium. Written informed consent was obtained from each patient and the study was approved by the Gil hospital 
ethics committee. Tumor fragments were implanted into subcutaneous pockets of mice, which were made in each side of the lower back. When the tumor size reached to $100 \sim 200 \mathrm{~mm}^{3}$, those samples were called $F_{1}$, subsequently divided into pieces for passaging in vivo to make $F_{2}$ xenograft tumors. When F2 tumor size reached to $100 \sim$ $200 \mathrm{~mm}^{3}$, collected and cut into $1 \sim 2 \mathrm{~mm}^{3}$ sized pieces and implanted into subcutaneous layer on the backs of mice to make F3. When F3 tumor size reached to 100 $200 \mathrm{~mm}^{3}$, mice were randomly divided into 4 groups with 5 mice per each group. Mutation status of important cancer-related genes and patient information of colon PDTX samples is listed in Table 1.

One group was treated twice per week with intraperitoneal injection of $5 \mathrm{mg} / \mathrm{kg}$ oxaliplatin in PBS and other groups were treated once daily orally with low dose $(250 \mathrm{mg} / \mathrm{kg})$ or high dose $(500 \mathrm{mg} / \mathrm{kg})$ of BP3B dissolved in $0.5 \% \mathrm{Na}-\mathrm{CMC}$ $(\mathrm{w} / \mathrm{v})$. Tumor diameters were serially measured with a digital caliper every 2-3 days and tumor volumes were calculated using the following formula: $\mathrm{V}=\left(\mathrm{L} \times \mathrm{W}^{2}\right) / 2, \mathrm{~V}=$ volume, $\mathrm{L}$ = length and $\mathrm{W}=$ width. On day 21 , mice were sacrificed and tumor tissues were collected, fixed with $10 \%$ formalin and embedded in paraffin. Remaining tissues were kept on $-80{ }^{\circ} \mathrm{C}$ deepfreezer for isolating protein and RNA.

\section{TUNEL assay}

Terminal deoxynuclotidyl transferase-mediated deoxyuridine triphosphate nick-end-labeling (TUNEL) assay was performed to measure nuclear DNA fragmentation in apoptotic cells using DeadEnd ${ }^{\mathrm{TM}}$ Fluorometric TUNEL System (Promega, Madison, WI), according to the manufacturer's instruction. In brief, paraffin sections of colon tumor samples were deparaffinized in xylene and rehydrated in a series of graded alcohols and fixed in $4 \%$ paraformaldehyde for $30 \mathrm{~min}$ and permeabilized with $20 \mu \mathrm{g} / \mathrm{ml}$ proteinase $\mathrm{K}$ for $10 \mathrm{~min}$ at room temperature. The tissue section were then incubated with TUNEL reaction buffer

Table 1 Characteristics of PDTX patient samples

\begin{tabular}{lll}
\hline & $115 \mathrm{~F}$ & $102 \mathrm{~F}$ \\
\hline Age & 83 & 50 \\
Sex & $\mathrm{F}$ & $\mathrm{F}$ \\
pT (primary status) & 3 & $4 \mathrm{a}$ \\
pM (distant metastasis) & 0 & 1 \\
pN (Lymph node status) & 0 & $2 \mathrm{~b}$ \\
Tumor cell type & Adenocarcinoma, & Adenocarcinoma, \\
& Moderately & Moderately \\
& differentiated & differentiated \\
Microsatellite instability & Stable & Stable \\
KRAS mutation status & G13D & WT \\
EGFR overexpression & - & - \\
p53 expression & + & + \\
\hline
\end{tabular}

in a $37{ }^{\circ} \mathrm{C}$ humidified chamber for $1 \mathrm{~h}$, rinsed twice with 2xSSC and PBS and then incubated with DAPI for $1 \mathrm{~min}$ at room temperature. Stained apoptotic cells were visualized by fluorescence microscopy.

\section{Immunohistochemistry and immunofluorescence assay}

Paraffin sections of colon tumor samples were deparaffinized in xylene and rehydrated in a series of graded alcohols and antigen was retrieved in $0.01 \mathrm{M}$ sodium citrate buffer. Samples were incubated with $3 \% \mathrm{H}_{2} \mathrm{O}_{2}$ for $10 \mathrm{~min}$ and followed by $1 \mathrm{~h}$ blocking in $1 \%$ bovine serum albumin in PBS. The slides were incubated overnight at $4{ }^{\circ} \mathrm{C}$, followed by incubating sections with secondary antibody using $\mathrm{ABC}$ kit (Vector laboratories) for $1 \mathrm{~h}$ at room temperature. Then, samples were developed with diaminobezidine (Vector Laboratories) reagent and counterstained with hematoxylin and mounted with permount.

To quantify the immunostaining intensity of TUNEL, Ki67, CD31 or Tie-2-positive cells, we used and ImmunoRatio software by analyzing the control and treatment groups. The percentage of positively stained nuclear area was calculated by using a color deconvolution for separating the staining components (diaminobezidine and hematoxylin) in at least 3 fields per each slide. The results were presented as percentage of treated group compared to control one.

\section{Western blot analysis}

Collected colon tumor tissues were lysed in a buffer containing $25 \mathrm{mM}$ HEPES (pH 7.5), $150 \mathrm{mM} \mathrm{NaCl}, 1 \%$ Triton X-100, 10\% glycerol, 5 mM EDTA and a protease inhibitor cocktail. Protein concentration was determined using the bicinchoninic acid assay. For western blotting, equal amount of proteins were separated by SDS-polyacrylamide gel electrophoresis, followed by transfer to Immobilon ${ }^{\circledR} \mathrm{P}$ PVDF transfer membrane (Millipore, Bedford, MA). After immunoblotting using specific antibodies, proteins were visualized by chemiluminescence, according to the manufacturer's instructions (Pierce, Rockford, IL).

\section{Statistical analysis}

These results were represented as the mean \pm SD values. The differences between groups were determined using 2 -tailed student's tests and the differences were considered significant when the $P$-values were $\leq 0.05$.

\section{Results}

\section{BP3B significantly inhibits tumorigenic growth in PDTX model}

To investigate the ability of $\mathrm{BP} 3 \mathrm{~B}$ on the inhibition of tumor growth in vivo, $n u / n u$ mice were implanted with different types (102 F and $115 \mathrm{~F}$ ) of patient colon tumors and assigned to the following four groups ( $\mathrm{n}=5$ mice per patient per treatment group) for treatment with $0.5 \% \mathrm{Na}$ CMC only (control), oxaliplatin ( $5 \mathrm{mg} / \mathrm{kg}$ ), $250 \mathrm{mg} / \mathrm{kg}$ or 
$500 \mathrm{mg} / \mathrm{kg}$ of BP3B. As shown in Fig. 1a and b, BP3B administration significantly retarded tumor growth by $\sim 70 \%$ compared with control mice. Body weights of the mice were not significantly altered by BP3B administration compared with those of the control group (Fig. 1c) and any defects of other tissues or organs were found in mice. These results suggest that BP3B significantly suppressed tumorigenic growth and did not cause any severe toxicity.

\section{Histology analysis of xenograft tumors}

To obtain more complete insight into the inhibitory effect of BP3B on tumor growth, histological studies on tumor tissue sections with $H \& E$ staining were performed. As shown in Fig. 2, tumor cells in the control group had well-defined cell borders and hyperchromatic nuclei (a and e). However, tumors treated with oxaliplatin $(5 \mathrm{mg} / \mathrm{kg}$ ) (b and f), $250 \mathrm{mg} /$ $\mathrm{kg}$ (c and g) or $500 \mathrm{mg} / \mathrm{kg}$ ( $\mathrm{d}$ and $\mathrm{h}$ ) of BP3B showed significant differences from the corresponding control groups. For instance, tumor cells were accompanied by chromatin condensation, formation of apoptotic bodies. Especially, high dose BP3B-treated tumor tissues revealed more clear apoptotic characteristics and cell death phenotype.

\section{BP3B treatment promotes apoptotic cell death in xenograft tumors}

Based on previous study, we hypothesized that BP3B may have anti-tumor activity through induction of cancer cell apoptosis. Therefore, we assessed whether antitumor activities of BP3B in colon cancer xenografts are exerted through activation of apoptosis. An apoptosis detection kit (TUNEL) was used to identify apoptotic cell death induced by BP3B. As shown in Fig. 3a, oxaliplatin $(5 \mathrm{mg} / \mathrm{kg})$, low dose $(250 \mathrm{mg} / \mathrm{kg})$ and high dose $(500 \mathrm{mg} / \mathrm{kg})$ of BP3B -treated tumor tissues showed significant apoptosis index compared with control group. We also confirmed BP3B mediated cell apoptosis using western blot analysis (Fig. 3b). As a marker for apoptosis, degradation of PARP and activation of Caspase 3 proteins were detected in PDTX samples. As expected, PARP was degraded in drug-treated samples. In opposite way, activated Caspase 3 was increased in two types of PDTX tissues by treatment of BP3B. Although there were no high differences between oxaliplatin and high dose of BP3B-treated $102 \mathrm{~F}$ tumors in TUNEL assay, western blot analysis shown the reliable differences of apoptosis between two groups. These data indicate that BP3B induced apoptosis to suppress the tumor growth in PDTX model.

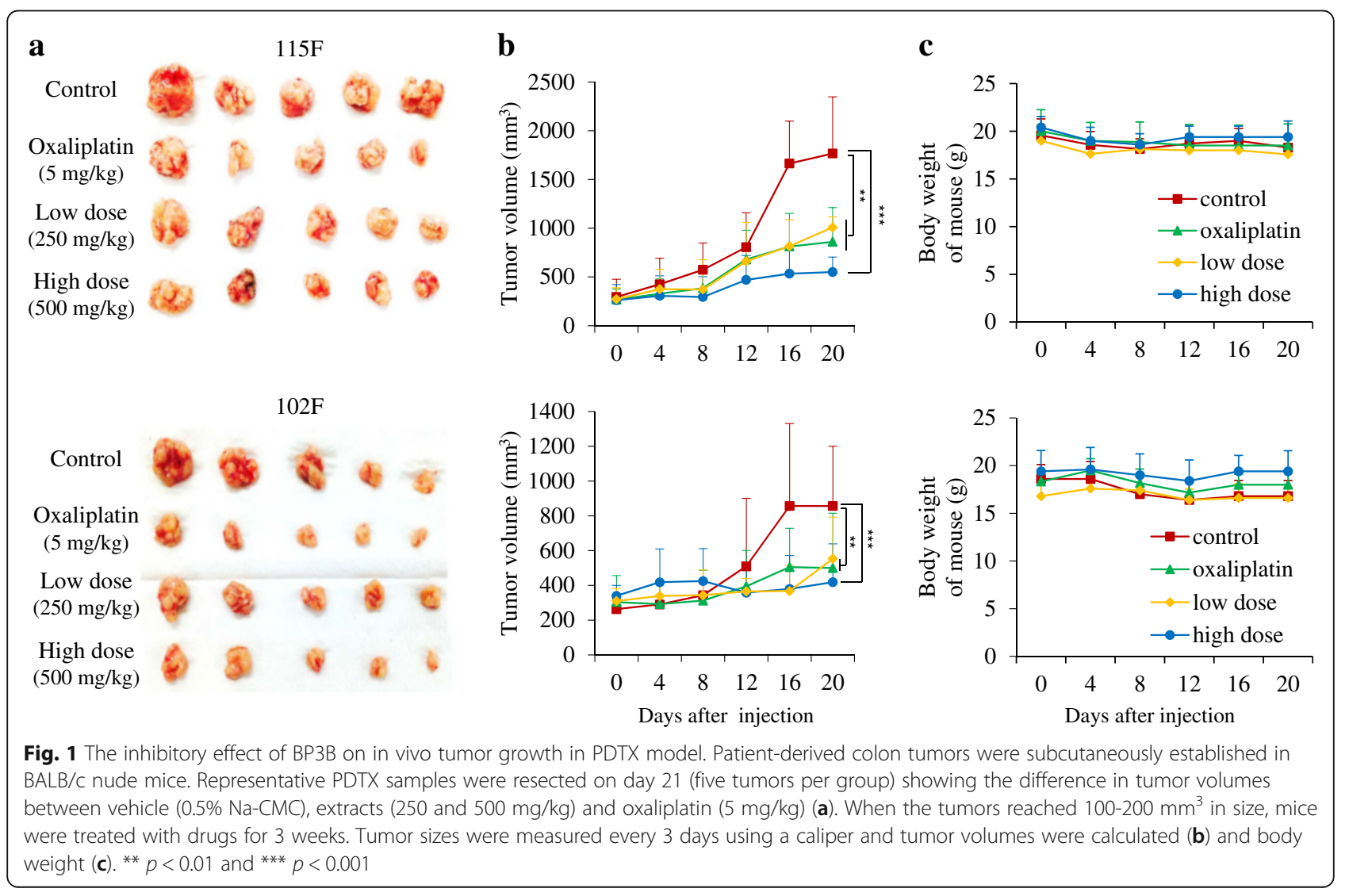



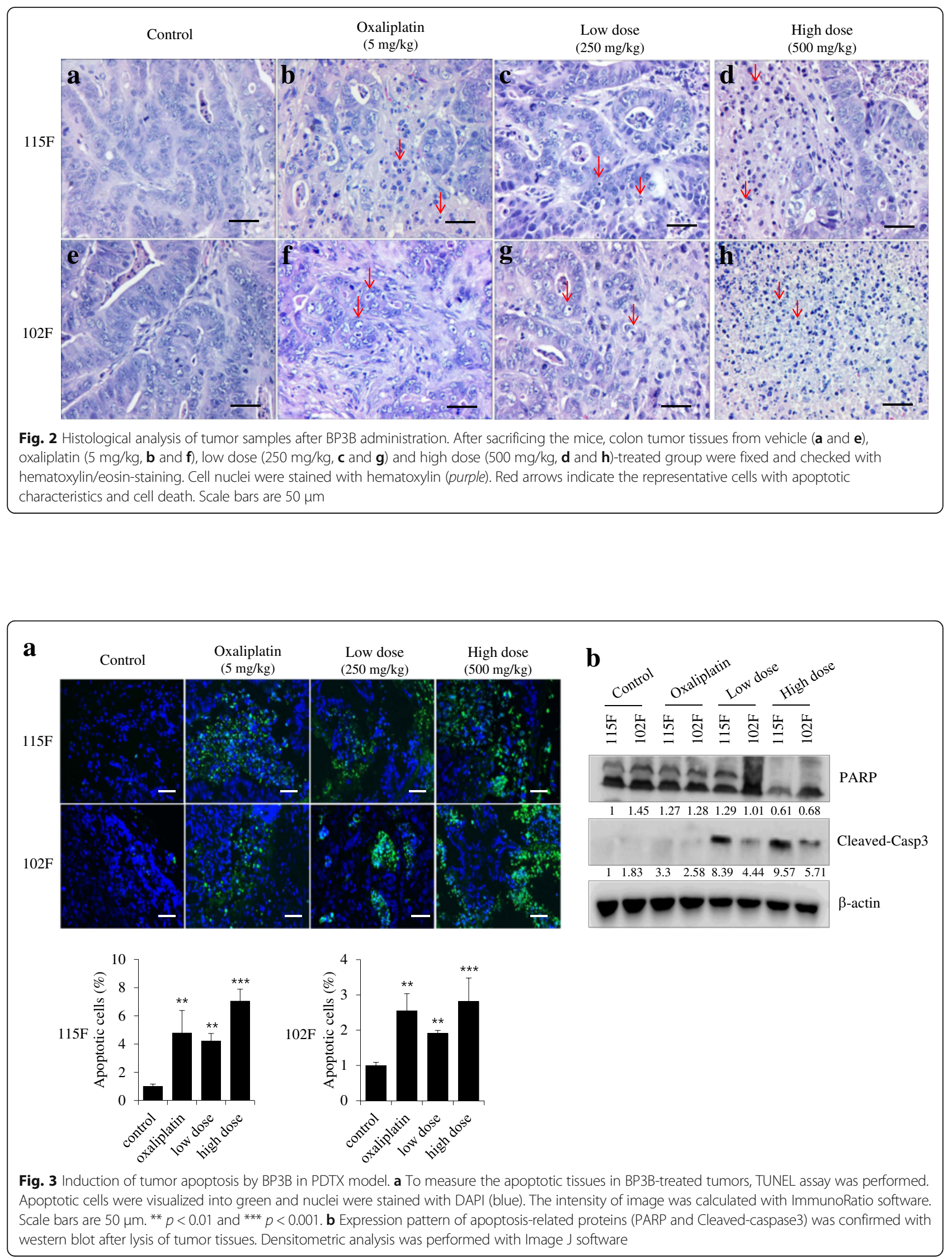
BP3B regulates cell cycle related proteins in PDTX models To investigate the effect of $\mathrm{BP} 3 \mathrm{~B}$ on the proliferation of colon cancer cells, we first conducted an immunohistochemistry using intrinsic proliferation marker, Ki67. As shown in Fig. 4a, Ki67 positive cells were highly detected in control groups compared with oxaliplatin and BP3Btreated tumor tissues. This result suggests that BP3B significantly suppresses cell proliferation of in vivo PDTX tumor. To further understand how BP3B inhibits colon cancer cell proliferation, the effect of $\mathrm{BP} 3 \mathrm{~B}$ on the cell cycle regulators, p27 and cyclin D1, was checked using western blot analysis. As shown in Fig. 4b, cyclin D1 expression was reduced, but p27 expression was increased upon treatment with BP3B. Especially, high dose of BP3B $(500 \mathrm{mg} / \mathrm{kg})$ induced significant reduction of cyclin D1 and increase of p27. These results suggest that BP3B inhibits cancer cell proliferation and induces apoptosis by regulating cell cycle related proteins.

\section{BP3B suppresses angiogenesis in xenograft tumors}

Angiogenesis has been known well as an important role in tumor growth, progression and metastasis [25-27] Therefore, we further examined whether BP3B inhibits angiogenesis in xenograft model. Immunofluorescence staining with antibodies against CD31 and Tie-2 revealed that vehicletreated group formed intact blood vessel in tumor samples.
However, oxaliplatin and BP3B-treated groups showed markedly decreased angiogenesis in tumor tissues (Fig. 5 and Additional file 1: Figure S1). These data suggest that $\mathrm{BP} 3 \mathrm{~B}$ also inhibits the formation of neo-angiogenesis in PDTX tissues.

\section{Discussion}

KIOM-CRC\#BP3B is a novel herbal prescription that is composed of three plant materials in equal weighs. Descurainia sophia (L.) Weeb ex Prantl (Flixweed) is a member of the family Brassicaceae that is widely distributed in northeastern China and its seed has been broadly used in folk medicine as a cure for throat diseases and viral diseases such as measles and smallpox. Several studies of this plant material have reported that it contains diverse secondary metabolites including cardiac glycoside, flavonoids, lactones, lipids, nor-lignans, and coumarins with various biological activities such as cytotoxicity and anti-inflammatory activity $[28,29]$. The dried roots of Peucedanum praeruptorum Dunn (Family Umbelliferae) are a well-known traditional Chinese medicine. Several phytochemical and pharmacological studies have shown that various coumarins are the major constituents of this plant and these have diverse biological properties such as anti-inflammatory, chemopreventive and neuroprotective effects [30-32]. Alnus japonica is a member of the Family Betulaceae, and

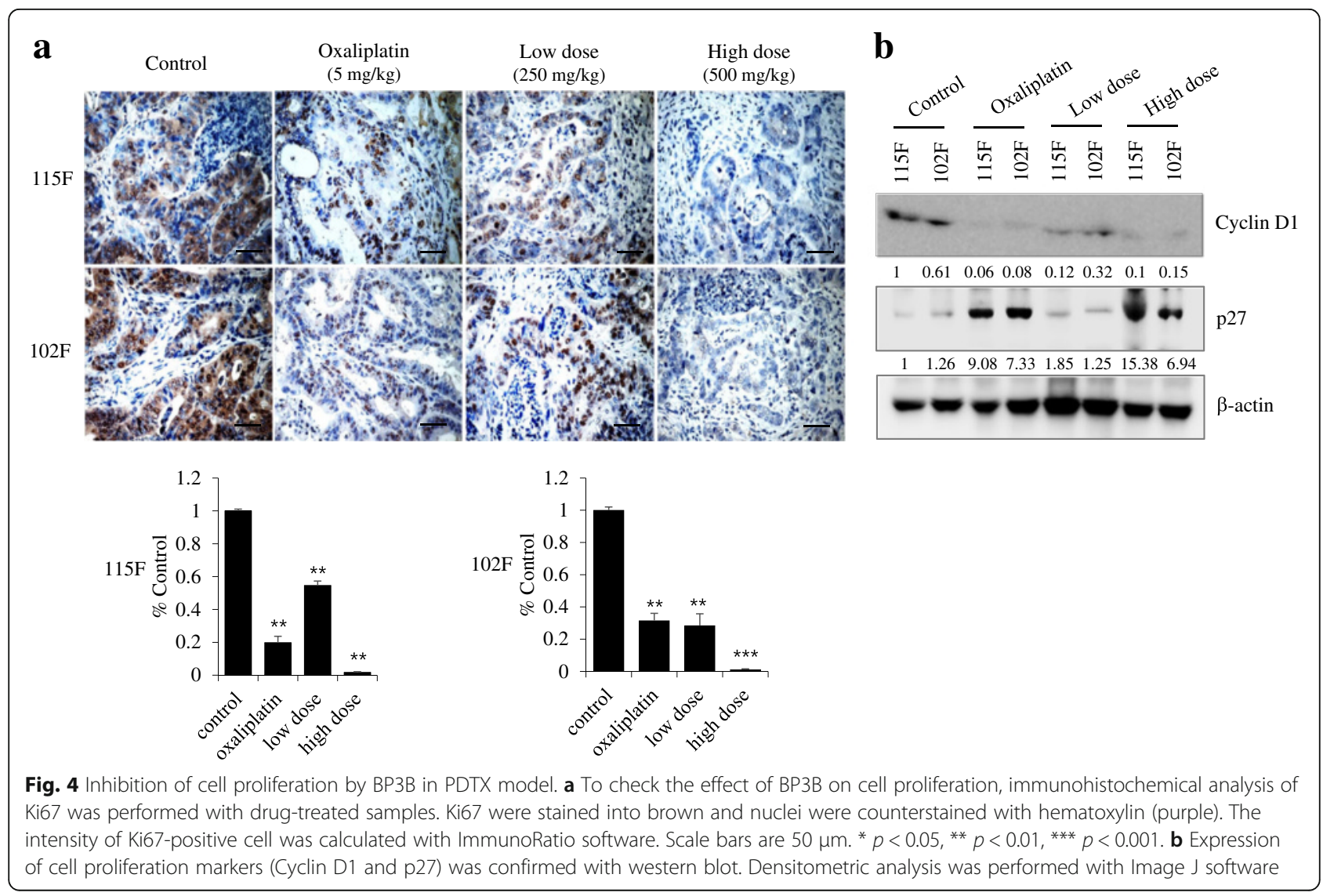




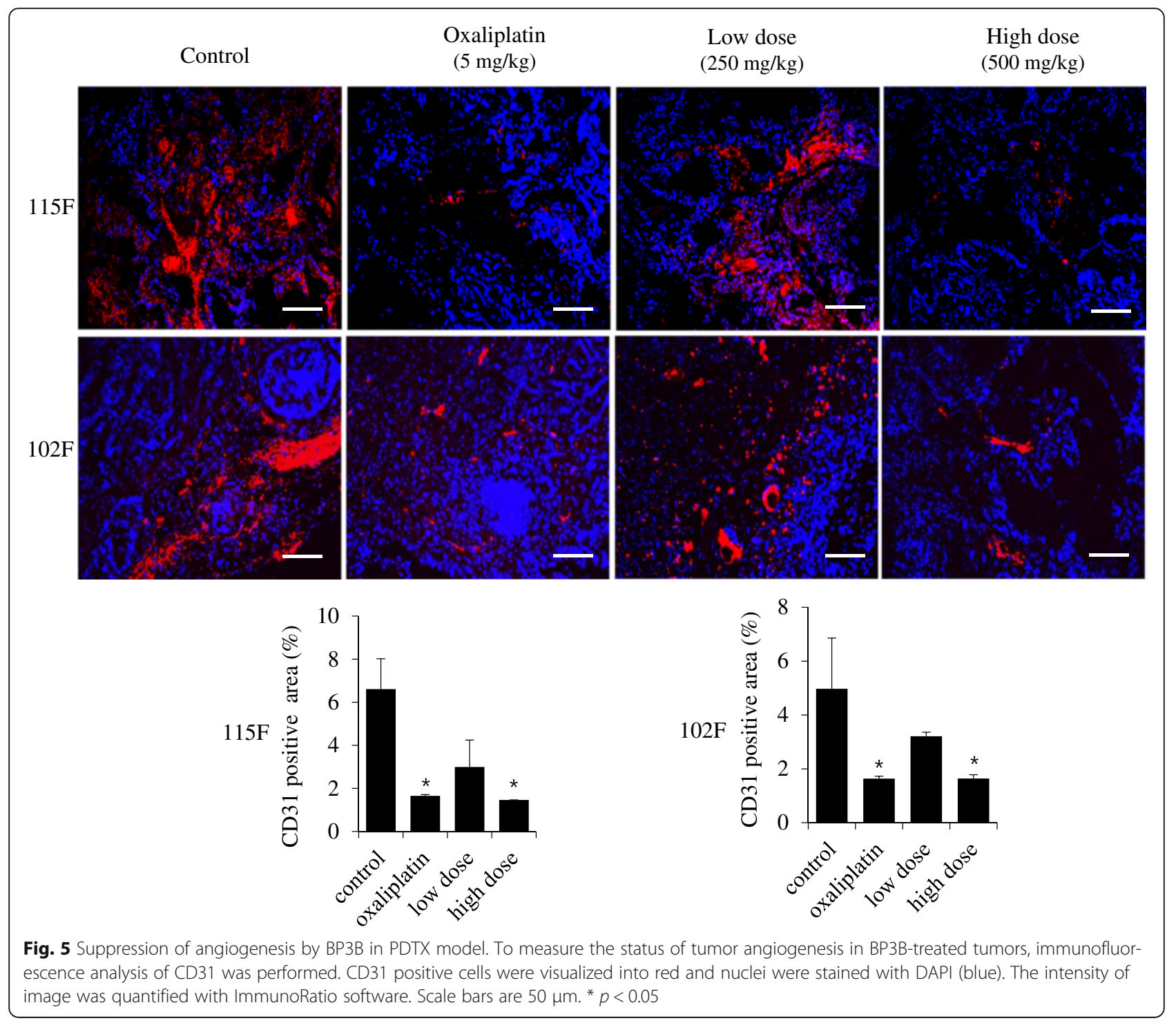

the bark of this plant has long been used in traditional medicine in the treatment of fever, hemorrhage, diarrhea, and alcoholism. Several scientific studies revealed that the extract of A. japonica contains various biological compounds with anti-adipogenic, anti-proliferative, and antiparasitic activities [33, 34]. In this study, we showed that BP3B have similar or better therapeutic efficacy compared with oxaliplatin (Fig. 1). Because herbal drugs have been known to exhibit fewer side effects (12), combination therapy with already clinically used drugs, such as oxaliplatin or irrinotecan can increase the anti-cancer activity and show synergistic effect of chemotherapy. Although we did not identify the exact mechanism for anti-tumorigenic activity of $\mathrm{BP} 3 \mathrm{~B}$, it will be very valuable information for further study and clinical trial.

Preclinical trial for validation of potential therapeutic targets via in vivo model is regarded as an indispensable procedure for anti-cancer drug development and make the conquest of cancer or other diseases [35]. Recently, many studies have adopted the PDTX technique to perform the preclinical testing of anti-cancer drugs [36]. Previous studies also indicated that transplantation of fresh surgical specimens better represents the cellular and clinical phenotypes of human cancers compared with traditional cell linebased preclinical testing [37, 38]. Histological examination also showed that PDTX model exhibited very similar histology and immunohistochemical phenotypes of patient's original tumors and maintained the invasive/metastatic features even during serial subtransplantations in vivo. According to their gene expression patterns in breast cancer samples, less than $5 \%$ of genes showed variation in expression between PDTX and the homologous primary tumor $[37,39]$. Although we did not present in this paper, we also confirmed that the xenograft tumors $\left(\mathrm{F}_{3}\right)$ exhibited similar 
histologic architecture and pathologic characteristics to that of the original tumors [38]. Established PDTX models of colon cancer were good systems for evaluating the efficacy of anti-tumor drug (Fig. 1). In addition, these models will provide very important tools for developing the novel drugs against drug-resistant tumors, such as cetuximab, using Ras wild-type and mutant samples.

\section{Conclusion}

This study indicated that ethanol extract of dried seeds of Descurainia sophia, roots of Peucedanum praeruptorum Dunn. and branches of Alnus japonica has a strong growth-inhibitory activity against colon cancer in patientderived tumor xenograft model. BP3B will be a good therapeutic candidate for treatment of refractory colon cancer.

\section{Additional file}

Additional file 1: Figure S1. To measure the status of tumor angiogenesis in BP3B-treated tumors, immunostaining of Tie-2 receptor tyrosine kinase was performed with specific antibody (brown). The intensity of Tie-2-positive cell was quantified with ImmunoRatio software. Cell nuclei were stained with hematoxylin (blue). Scale bars are $50 \mathrm{~mm} .{ }^{*} \mathrm{p}<0.05$. (PDF $421 \mathrm{~kb}$ )

\section{Abbreviations}

BP3B: KIOM-CRC\#BP3B; FU: Fluorouracil; LV: Leucovorin; PDTX: Patient-derived tumor xenograft; TUNEL: Terminal deoxynuclotidyl transferase-mediated deoxyuridine triphosphate nick-end-labeling

\section{Acknowledgement}

This research was supported by a grant from the Korea Institute of Oriental Medicine (K14062), from the Korean Health Technology R\&D Project, Ministry of Health \& Welfare, Republic of Korea (HI13C1364) and from the Gil Medical Center, Gachon University (FRD2014-09) to S. Hong.

\section{Funding}

This research was supported by a grant from the Korea Institute of Oriental Medicine (K14062), from the Korean Health Technology R\&D Project, Ministry of Health \& Welfare, Republic of Korea (HI13C1364) and from the Gil Medical Center, Gachon University (FRD2014-09) to S. Hong.

\section{Availability of data and materials}

The data and materials will be freely available to any scientist wishing to use them for non-commercial purposes

\section{Authors' contributions}

$\mathrm{BO}$ and $\mathrm{SH}$ designed this study. HK, JK and HTHT performed the experiments, prepared the plant extracts and analyzed the data. WL collected human colorectal tumor tissues. HK, JK and SH read and revised the paper. All authors read and approved the paper before its final submission.

\section{Competing interests}

The authors declare that they have no competing interests.

\section{Consent for publication}

We got a consent form for publication of our study from patients who provide their tissues after surgery.

\section{Ethics approval and consent to participate}

All experiments using immunodeficient mice were carried out in accordance with the guidelines approved by Institutional Animal Care and Use Committees of Gachon University (LCDI-2012-0039). Written informed consent was obtained from each patient and the study was approved by the Gil hospital ethics committee (GIRBA2779-2012).

\section{Author details}

1 Department of Biochemistry, Lee Gil Ya Cancer and Diabetes Institute, Gachon University, 155 Gaetbel-ro Yeonsu-gu, Incheon 21999, Republic of Korea. ${ }^{2}$ KM-Convergence Research Division, Korea Institute of Oriental Medicine, Daejeon 34054, Republic of Korea. ${ }^{3}$ Department of Sugery, Gil Medical Center, Gachon University, Incheon 21565, Republic of Korea.

Received: 23 May 2016 Accepted: 3 November 2016

Published online: 18 November 2016

\section{References}

1. Walther A, Johnstone E, Swanton C, Midgley R, Tomlinson I, Kerr D. Genetic prognostic and predictive markers in colorectal cancer. Nat Rev Cancer. 2009;9:489-99.

2. Buyse M, Thirion P, Carlson R, Burzykowski T, Molenberghs G, Piedbois P. Tumour response to first line chemotherapy improves the survival of patients with advanced colorectal cancer. Lancet. 2000;356:373-8.

3. Saltz LB, Cox JV, Blanke C, Rosen LS, Fehrenbacher L, Moore MJ, Maroun JA, Ackland SP, Locker PK, Pirotta N, Elfring GL, Miller LL. Irinotecan plus fluorouracil and leucovorin for metastatic colorectal cancer. Irinotecan Study Group. N Engl J Med. 2000;343:905-14.

4. Douillard J, Cunningham D, Roth A, Navarro M, James R, Karasek $P$, Jandik $P$, Iveson T, Carmichael J, Alakl M. Irinotecan combined with fluorouracil compared with fluorouracil alone as first-line treatment for metastatic colorectal cancer: a multicentre randomised trial. Lancet. 2000;355:1041-7.

5. Knight R, Miller L, Pirotta N, Elfring G, Locker P, Saltz L. First-line irinotecan $(C)$, fluorouracil (F), leucovorin (L) especially improves survival (OS) in metastatic colorectal cancer (MCRC) patients (PT) with favorable prognostic indicators. Proc Am Soc Clin Oncol. 2000;19:991a.

6. de Gramont AD, Figer A, Seymour M, Homerin M, Hmissi A, Cassidy J, Boni C, Cortes-Funes H, Cervantes A, Freyer G. Leucovorin and fluorouracil with or without oxaliplatin as first-line treatment in advanced colorectal cancer. J Clin Oncol. 2000;18:2938-47.

7. Young A, Rea D. ABC of colorectal cancer: treatment of advanced disease. BMJ. 2000;321:1278-81.

8. lacovelli R, Pietrantonio F, Maggi C, de Braud F, Di Bartolomeo M. Combination or single-agent chemotherapy as adjuvant treatment of gastric cancer: A systematic review and meta-analysis of published trials. Crit Rev Oncol Hematol. 2015;\$1040:30043.

9. Saito RF, Tortelli TC, Jacomassi MD, Otake AH, Chammas R. Emerging targets for combination therapy in melanomas. FEBS Lett. 2015;589:3438-48.

10. Hazama S, Nakamura Y, Tanaka H, Hirakawa K, Tahara K, Shimizu R, Ozasa H, Etoh R, Sugiura F, Okuno K, Furuya T, Nishimura T, Sakata K, Yoshimatsu K, Takenouchi H, Tsunedomi R, Inoue Y, Kanekiyo S, Shindo Y, Suzuki N, Yoshino S, Shinozaki H, Kamiya A, Furukawa H, Yamanaka T, Fujita T, Kawakami Y, Oka M. A phase lotal study of five peptides combination with oxaliplatin-based chemotherapy as a first-line therapy for advanced colorectal cancer (FXV study). J Transl Med. 2014;12:108.

11. Dorff TB, Groshen S, Tsao-Wei DD, Xiong S, Gross ME, Vogelzang N, Quinn DI, Pinski JK. A Phase II trial of a combination herbal supplement for men with biochemically recurrent prostate cancer. Prostate Cancer Prostatic Dis. 2014;17:359-65.

12. Lam W, Bussom S, Guan F, Jiang Z, Zhang W, Gullen EA, Liu SH, Cheng YC. The four-herb Chinese medicine PHY906 reduces chemotherapy-induced gastrointestinal toxicity. Sci Transl Med. 2010;2:45ra59.

13. Sausville EA, Burger AM. Contributions of human tumor xenografts to anticancer drug development. Cancer Res. 2006;66:3351-4.

14. Boedigheimer MJ, Freeman DJ, Kiaei P, Damore MA, Radinsky R. Gene expression profiles can predict panitumumab monotherapy responsiveness in human tumor xenograft models. Neoplasia. 2013;15:125-32.

15. Daniel VC, Marchionni L, Hierman JS, Rhodes JT, Devereux WL, Rudin CM, Yung R, Parmigiani G, Dorsch M, Peacock CD, Watkins DN. A primary xenograft model of small-cell lung cancer reveals irreversible changes in gene expression imposed by culture in vitro. Cancer Res. 2009;69:3364-73.

16. Marangoni E, Vincent-Salomon A, Auger N, Degeorges A, Assayag F, de Cremoux P, de Plater L, Guyader C, De Pinieux G, Judde JG, Rebucci M, Tran-Perennou C, Sastre-Garau X, Sigal-Zafrani B, Delattre O, Dieras V, Poupon MF. A new model of patient tumor-derived breast cancer xenografts for preclinical assays. Clin Cancer Res. 2009;13:3989-98.

17. Fiebig HH, Maier A, Burger AM. Clonogenic assay with established human tumour xenografts: correlation of in vitro to in vivo activity as a basis for anticancer drug discovery. Euro J Cancer. 2004;40:802-20. 
18. Jin K, Teng L, Shen Y, He K, Xu Z, Li G. Patient-derived human tumour tissue xenografts in immunodeficient mice: a systematic review. Clin Transl Oncol. 2010;12:473-80.

19. Lee YJ, Kim NS, Kim H, Yi JM, Oh SM, Bang OS, Lee J. Cytotoxic and antiinflammatory constituents from the seeds of Descurainia sophia. Arch Pharm Res. 2013:36:536-41.

20. Khan M, Xiao Y, Yu B, Wang N, Rasul A, Yi F, Yang L, Yang H, Ma T. Artabotryside A, a constituent from Descurainia sophia (L.) induces cell death in U87 glioma cells through apoptosis and cell cycle arrest at G2/M phase. J Med Plants Res. 2012;6:3754-65.

21. Sun K, Li X, Li W, Wang J, Liu J, Sha Y. Two new lactones and one new aryl8-oxa-bicyclo[3,2,1] oct-3-en-2-one from Descurainia sophia. Chem Pharm Bull. 2004;52:1483-6.

22. Lee J, Lee YJ, Kim J, Bang OS. Pyranocoumarins from root extracts of Peucedanum praeruptorum Dunn with multidrug resistance reversal and anti-inflammatory activities. Molecules. 2015;20:20967-78.

23. Uto T, Tung NH, Appiah-Opong R, Aning A, Morinaga O, Edoh D, Nyarko K, Shoyama Y. Antiproliferative and pro-apoptotic activity of diarylheptanoids isolated from the bark of alnus japonica in human leukemia cell lines. Am J Chin Med. 2015;43:757-67.

24. Kang S, Kim JE, Li Y, Jung SK, Song NR, Thimmegowda NR, Kim BY, Lee HJ, Bode AM, Dong Z, Lee KW. Hirsutenone in Alnus extract inhibits akt activity and suppresses prostate cancer cell proliferation. Mol Carcinog. 2015;54: 1354-62.

25. Horak ER, Leek R, Klenk N, LeJeune S, Smith K, Stuart N, Greenall M, Stepniewska K, Harris AL. Angiogenesis, assessed by platelet/endothelial cell adhesion molecule antibodies, as indicator of node metastases and survival in breast cancer. Lancet. 1992;340:1120-4.

26. Toi M, Kashitani J, Tominaga T. Tumor angiogenesis is an independent prognostic indicator in primary breast carcinoma. International journal of cancer. Int J Cancer. 1993;55:371-4.

27. Weidner N, Folkman J, Pozza F, Bevilacqua P, Allred EN, Moore DH, Meli S, Gasparini G. Tumor angiogenesis: a new significant and independent prognostic indicator in early-stage breast carcinoma. J Nat Cancer Inst. 1992; 84:1875-87.

28. Khodarahmi E, Asghari GH, Hassanzadeh F, Mirian M, Khodarahmi GA Cytotoxic evaluation of volatile oil from Descurainia sophia seeds on MCF-7 and HeLa cell lines. Res Pharm Sci. 2015;10:169-76.

29. Yu PJ, Jin H, Zhang JY, Wang GF, Li JR, Zhu ZG, Tian YX, Wu SY, Xu W, Zhang JJ, Wu SG. Pyranocoumarins isolated from Peucedanum praeruptorum Dunn suppress lipopolysaccharide-induced inflammatory response in murine macrophages through inhibition of NF-kappaB and STAT3 activation. Inflammation. 2012;35:967-77.

30. Liang T, Yue W, Li Q. Chemopreventive effects of Peucedanum praeruptorum DUNN and its major constituents on SGC7901 gastric cancer cells. Molecules. 2010;15:8060-71.

31. Yang L, Li XB, Yang Q, Zhang K, Zhang N, Guo YY, Feng B, Zhao MG, Wu $Y M$. The neuroprotective effect of praeruptorin $C$ against NMDA-induced apoptosis through down-regulating of GluN2B-containing NMDA receptors. Toxicol In Vitro. 2013;27:908-14.

32. Sung SH, Lee M. Anti-adipogenic activity of a new cyclic diarylheptanoid isolated from Alnus japonica on 3 T3-L1 cells via modulation of PPARgamma, C/EBPalpha and SREBP1c signaling. Bioorg Med Chem Lett. 2015;25:4648-51

33. Tung $\mathrm{NH}$, Suzuki $M$, Uto $T$, Morinaga $\mathrm{O}$, Kwofie KD, Ammah $N$, Koram KA, Aboagye F, Edoh D, Yamashita T, Yamaguchi Y, Setsu T, Yamaoka S, Ohta N, Shoyama Y. Anti-trypanosomal activity of diarylheptanoids isolated from the bark of Alnus japonica. Am J Chin Med. 2014;42 1245-60.

34. Gura T. Systems for identifying new drugs are often faulty. Science. 1997; 278:1041-2.

35. Zhao X, Liu Z, Yu L, Zhang Y, Baxter P, Voicu H, Gurusiddappa S, Luan J, Su $J M$, Leung HC, Li XN. Global gene expression profiling confirms the molecular fidelity of primary tumor-based orthotopic xenograft mouse models of medulloblastoma. Neuro Oncol. 2012;14:574-83.

36. Reyal F, Guyader C, Decraene C, Lucchesi C, Auger N, Assayag F, De Plater L, Gentien D, Poupon MF, Cottu P, De Cremoux P, Gestraud P, VincentSalomon A, Fontaine JJ, Roman-Roman S, Delattre O, Decaudin D, Marangoni E. Molecular profiling of patient-derived breast cancer xenografts. Breast Cancer Res. 2012:14:R11.
37. Gutmann DH, Maher EA, Van Dyke T. Mouse models of human cancers consortium workshop on nervous system tumors. Cancer Res. 2006;66:10-3.

38. Lee WS, Kim HY, Seok JY, Jang HH, Park YH, Kim SY, Shin DB, Hong S. Genomic profiling of patient-derived colon cancer xenograft models. Medicine. 2014;93:e298.

39. Martinez-Garcia R, Juan D, Rausell A, Munoz M, Banos N, Menendez C, Lopez-Casas PP, Rico D, Valencia A, Hidalgo M. Transcriptional dissection of pancreatic tumors engrafted in mice. Genome Med. 2014;6:27.

\section{Submit your next manuscript to BioMed Central and we will help you at every step:}

- We accept pre-submission inquiries

- Our selector tool helps you to find the most relevant journal

- We provide round the clock customer support

- Convenient online submission

- Thorough peer review

- Inclusion in PubMed and all major indexing services

- Maximum visibility for your research

Submit your manuscript at www.biomedcentral.com/submit
) Biomed Central 